\title{
Effect of Different Wrapping Films on Quality and Storability of Globe Artichoke during Cold Storage.
}

\author{
Salah E.A. Mohamedien, Mohsen EL-M. Saad and M.A. Saleh \\ Horticulture Research Institute, Agricultural Research Center, Giza, Egypt. \\ * Corresponding author: Giza_Lab2016@yahoo.com
}

\begin{abstract}
Artichoke heads of the cultivar "French Hyrious" were harvested at the suitable maturity stage of marketing with a dimension of $(7-12 \mathrm{~cm})$ on $14^{\text {th }}$ and $16^{\text {th }}$ of Februaryin 2017 and 2018 seasons, respectively from Borg Elarab farm, Behera Governorate and shifted to the laboratory of Vegetable Handling Research Department, Horticultural Research Institute, Agricultural Research Center, Ministry of Agriculture, A.R.E. to evaluate the potential of wrapping filmspolypropylene, polyethylene and polyvinyl film in preserving the quality parameters and extend the shelf life of artichoke heads during cold storage. Wrapping artichoke heads in the different wrapping films slowed the rate of weight loss, had the highest compactness and gave the highest value of $\mathrm{L}$ value, resulted in lighter color comparatively to the highest ones obtained from unwrapped heads. Artichoke heads wrapped with polypropylene film or polyethylene film were perceived to have the highest intensities of freshness, greenness and compactness. Wrapping artichoke heads with polypropylene film produced an improvement in market quality; it would reduce weight loss percentage, color change and maintained ascorbic acid content and gave product with good appearance after 28 days of storage at $0{ }^{\circ} \mathrm{C}$ and $95 \% \mathrm{RH}$.
\end{abstract}

Key words: Artichoke heads, Wrapping films, Artichoke storability and quality and cold storage.

\section{Introduction}

Globe artichoke (Cynara scolymus L.) is considered as one of the important vegetable crops for local consumption and export in Egypt. The nutraceutical properties of artichokes are mainly due to its high polyphenolic content (Azzini et al., 2007), which can be up to $2 \%$ of the fresh weight (Mileo et $a l ., 2012$ ), and the presence of fructan inulin that has been reported to have a prebiotic function that stimulates the growth of intestinal bifido bacteria (Salazar et al., 2015 and Lavermicocca et al., 2016).

However, artichoke is a highly perishable commodity, characterized by rapid rates of respiration and water loss (Kader, 1992). The main factors of artichoke heads quality degradation during prolonged storage are mostly due to decay development shriveling, associated with rapid water loss, poor external appearance, as well as reduced sensory quality. Therefore, optimum temperature $(0$ $-1^{\circ} \mathrm{C}$ ) of storage was mainly the major factor for extending the storage ability of artichoke by minimizing both the physical, chemical and biochemical changes (Atala, 2006). In addition to refrigeration; wrapping film is one of the important supplemental tools to keep more good qualities for better marketing. Thus, it was found on globe artichoke that the stored heads at $4^{\circ} \mathrm{C}$ in polyethylene bags showed minimum loss in weight, unmarketable heads and maximum visual quality than the unpacked ones (Nobile et al., 2009). The use of selective plastic film for prolonging the storability of artichoke heads was studied by many investigators, as the selection of proper packaging is of crucial importance to create conditions able to guarantee the maintenance of product quality (Lucera et al., 2011). Further study on globe artichoke indicated that the heads stored at $5^{\circ} \mathrm{C}$ in perforated polypropylene films kept comparatively the highest content of ascorbic acid than those stored in polyvinyl chloride, polyethylene or micro perforated polypropylene bags after 8 days of storage (Gil-Izquierdo et al., 2002).

The objective of this work was to evaluate the potential of wrapping film in preserving the quality parameters and extend the shelf life of artichoke heads during cold storage.

\section{Materials and Methods}

Artichoke heads of the cultivar "French Hyrious" were harvested at the suitable maturity stage of marketing with a dimension of $(7-12 \mathrm{~cm})$ on $14^{\text {th }}$ and $16^{\text {th }}$ of Februaryin 2017 and 2018 season respectively from Borg El-arab farm, Behera Governorate and shifted to the laboratory of Vegetable Handling Research Department, Horticultural Research Institute, Agricultural Research Center, Ministry of Agriculture, A.R.E.

Heads were cleaned with dry towels, graded and put in carton boxes with a dimension of $(40 \times 30 \times 15$ $\mathrm{cm}$ ). Each box contained heads (three replicates, each replicate were three heads). Boxes were wrapped with polypropylene film $(30 \mu \mathrm{m}$ thickness),

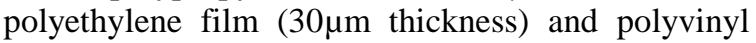
film $(35 \mu \mathrm{m}$ thickness) beside unwrapped (control). Four boxes were prepared for each treatment. All wrapping materials were stored at $0^{\circ} \mathrm{C}$ and $95 \%$ $\mathrm{RH}$ for 28 days. The experimental design was completely randomized design with three replicates. Three replicate from each treatment were taken at 
random and examined immediately after harvest and every 7 days at $0^{\circ} \mathrm{C}$ for the following properties.

Weight loss percentage calculated by the following equation: weight loss $\%=$ Loss in weight at the sampling date / the initial weight of the head $\mathrm{X} 100$. The general appearance: Score rating from 9 to 1 Where $9=$ excellent, $7=$ good, $5=$ fair, $3=$ poor and $1=$ inedible. The compactness: Score rating from 5 to 1 , where $5=$ tight, $4=$ few basal bracts pointing a way from rather than toward tip of bud, $3=$ several whorls of bracts pointing a way from rather than toward tip of bud, $2=$ all or most outer bracts open, $1=$ all outer and more antrally located bracts open. External surface color was evaluated by a color meter (Minolta CR 200) to measure the lightness (L value) and hue angle $\left(\mathrm{h}^{\circ}\right)$ value. Ascorbic acid content (as indicated for vit. C). It was determined (as fresh samples of heads) by titration method using 2,6dicloro phenol indophenols as described in (Ranganna, 1979).

\section{Statistical analysis}

Data were statistically analyzed using the analysis of variance described by Snedecor and Cochran (1980). The method of Duncan multiple range tests were applied for than comparison between means according to Waller and Duncan (1969).

\section{Results and Discussion}

Weight loss percentage
Data in Table (1) showed that weight loss percentage of artichoke heads was increased considerably and consistently with the prolongation of storage period. These results were in agreement with those obtained by (Helaly et al., 2016). The loss in weight may be attributed to respiration and other senescence related metabolic processes during storage (Wills et al., 1981).

Concerning the effect of wrapping films, different wrapping films showed significant differences in their heads weight loss percentage. In this respect, wrapping artichoke heads in the different wrapping films slowed the rate of weight loss comparatively to the highest ones obtained from unwrapped heads. Artichoke heads wrapped with polypropylene film was the most effective treatment in reducing the weight loss percentage followed by polyethylene film with significant differences between them. Polyvinyl film was less effective in this concern. These results were achieved in the two seasons and were in agreement with (Nobile et al., 2009), who fund that lowest weight loss from artichoke heads wrapped in different wrapping films is due to the confinement of moisture around the produce. This increases the relative humidity and reduces vapor pressure deficit and transpiration. In addition, wrapping films creates a modified atmosphere with high concentration of $\mathrm{CO}_{2}$ and reduced $\mathrm{O}_{2}$ around the produce which slows down metabolic processes and transpiration (Thompson, 1996), which diminished the weight loss \% during storage (Wang and Qi, 1997).

Table 1. Effect of different wrapping films on weight loss percentage of artichoke heads during storage in 2017 and 2018 seasons.

\begin{tabular}{|c|c|c|c|c|c|c|}
\hline \multirow{2}{*}{ Treatments } & \multicolumn{5}{|c|}{ Storage period in days } & \multirow{2}{*}{ means } \\
\hline & Start & 7 & 14 & 21 & 28 & \\
\hline \multicolumn{7}{|c|}{2017 season } \\
\hline Polypropylene film & $0.00 \mathrm{~K}$ & $1.47 \mathrm{~J}$ & $2.43 \mathrm{HI}$ & $4.40 \mathrm{G}$ & $4.92 \mathrm{G}$ & $2.65 \mathrm{D}$ \\
\hline Polyethylene film & $0.00 \mathrm{~K}$ & $1.75 \mathrm{IJ}$ & $2.45 \mathrm{HI}$ & $5.09 \mathrm{G}$ & $5.95 \mathrm{EF}$ & $3.05 \mathrm{C}$ \\
\hline Polyvinyl film & $0.00 \mathrm{~K}$ & $2.87 \mathrm{H}$ & $5.15 \mathrm{FG}$ & $6.31 \mathrm{E}$ & $8.53 \mathrm{D}$ & 4.57 B \\
\hline Control (unwrapped) & $0.00 \mathrm{~K}$ & $4.91 \mathrm{G}$ & $9.37 \mathrm{C}$ & $11.4 \mathrm{~B}$ & $14.09 \mathrm{~A}$ & $7.95 \mathrm{~A}$ \\
\hline Means & $2.75 \mathrm{D}$ & $4.85 \mathrm{C}$ & $6.80 \mathrm{~B}$ & $8.37 \mathrm{~A}$ & $0.15 \mathrm{E}$ & \\
\hline \multicolumn{7}{|c|}{2018 season } \\
\hline Polypropylene film & $0.00 \mathrm{O}$ & $1.59 \mathrm{~N}$ & $2.55 \mathrm{~L}$ & $4.52 \mathrm{~J}$ & $5.04 \mathrm{I}$ & $2.74 \mathrm{D}$ \\
\hline Polyethylene film & $0.00 \mathrm{O}$ & $1.87 \mathrm{M}$ & $2.57 \mathrm{~L}$ & $5.21 \mathrm{H}$ & $6.07 \mathrm{~F}$ & $3.14 \mathrm{C}$ \\
\hline Polyvinyl film & $0.00 \mathrm{O}$ & $3.13 \mathrm{~K}$ & $5.41 \mathrm{G}$ & $6.57 \mathrm{E}$ & $8.79 \mathrm{D}$ & $4.78 \mathrm{~B}$ \\
\hline Control (unwrapped) & $0.00 \mathrm{O}$ & $5.17 \mathrm{H}$ & $9.63 \mathrm{C}$ & $11.66 \mathrm{~B}$ & $14.35 \mathrm{~A}$ & $8.16 \mathrm{~A}$ \\
\hline Means & 0.00 E & $2.94 \mathrm{D}$ & $5.04 \mathrm{C}$ & $6.99 \mathrm{~B}$ & $8.56 \mathrm{~A}$ & \\
\hline
\end{tabular}

In general, the interaction between different wrapping films and storage period had significant effect on weight loss percentage. After 28 days of storage, the lowest value of weight loss was recorded from heads wrapped in polypropylene film while the highest ones were obtained from unwrapped film.

\section{General appearance (GA)}

Data in Table (2) revealed that there was significant reduction in GA with the prolongation of storage period. The decreases in GA of artichoke heads during storage might be due to shriveling with color change and decay (Nobile et al., 2009).

Regarding the effect of wrapping films on general appearance, data showed that all wrapping films had higher score of GA when compared with unwrapped heads. Artichoke heads wrapped with polypropylene 
film or polyethylene film were perceived to have the highest intensities of freshness, greenness and compactness with no significant differences between them, while unwrapped head was perceived to have low intensities of these attributes. These results were achieved in the two seasons and were in agreement with (Gil-Izquierdo et al., 2002 and Nobile et al., 2009).
The interaction between wrapping films and storage period revealed that artichoke heads wrapped with polypropylene film or polyethylene film gave good appearance after 28 days of storage at $0^{\circ} \mathrm{C}$, while heads which wrapped with polyvinyl film rated good appearance after 21 days of storage. On the other hand, unwrapped heads rated below fair appearance after 28 days of storage.

Table 2. Effect of different wrapping films on general appearance (score) of artichoke heads during storage in 2017 and 2018 seasons.

\begin{tabular}{|c|c|c|c|c|c|c|}
\hline \multirow{2}{*}{ Treatments } & \multicolumn{5}{|c|}{ Storage period in days } & \multirow{2}{*}{ means } \\
\hline & Start & 7 & 14 & 21 & 28 & \\
\hline \multicolumn{7}{|c|}{ 2017season } \\
\hline Polypropylene film & $9.00 \mathrm{~A}$ & $9.00 \mathrm{~A}$ & $9.00 \mathrm{~A}$ & $8.33 \mathrm{AB}$ & $7.67 \mathrm{BC}$ & $8.60 \mathrm{~A}$ \\
\hline Polyethylene film & $9.00 \mathrm{~A}$ & $9.00 \mathrm{~A}$ & $9.00 \mathrm{~A}$ & $7.67 \mathrm{BC}$ & 7.00 CD & 8.33 AB \\
\hline Polyvinyl film & $9.00 \mathrm{~A}$ & $9.00 \mathrm{~A}$ & $8.33 \mathrm{AB}$ & $7.00 \mathrm{CD}$ & $6.33 \mathrm{D}$ & $7.93 \mathrm{~B}$ \\
\hline Control (unwrapped) & $9.00 \mathrm{~A}$ & $9.00 \mathrm{~A}$ & 7.00 CD & $5.00 \mathrm{E}$ & $4.33 \mathrm{E}$ & $6.87 \mathrm{C}$ \\
\hline Means & $9.00 \mathrm{~A}$ & $9.00 \mathrm{~A}$ & 8.33 B & $7.00 \mathrm{C}$ & $6.33 \mathrm{D}$ & \\
\hline \multicolumn{7}{|c|}{2018 season } \\
\hline Polypropylene film & $9.00 \mathrm{~A}$ & $9.00 \mathrm{~A}$ & $9.00 \mathrm{~A}$ & $7.67 \mathrm{BC}$ & $7.00 \mathrm{C}$ & $8.33 \mathrm{~A}$ \\
\hline Polyethylene film & $9.00 \mathrm{~A}$ & $9.00 \mathrm{~A}$ & $8.33 \mathrm{AB}$ & $7.67 \mathrm{BC}$ & $7.00 \mathrm{C}$ & $8.20 \mathrm{~A}$ \\
\hline Polyvinyl film & $9.00 \mathrm{~A}$ & $9.00 \mathrm{~A}$ & 7.67 BC & $7.00 \mathrm{C}$ & $5.00 \mathrm{D}$ & $7.53 \mathrm{~B}$ \\
\hline Control (unwrapped) & $9.00 \mathrm{~A}$ & $9.00 \mathrm{~A}$ & $7.00 \mathrm{C}$ & $5.00 \mathrm{D}$ & $3.67 \mathrm{E}$ & $6.73 \mathrm{C}$ \\
\hline Means & $9.00 \mathrm{~A}$ & $9.00 \mathrm{~A}$ & $8.00 \mathrm{~B}$ & $6.83 \mathrm{C}$ & $5.67 \mathrm{D}$ & \\
\hline
\end{tabular}

Means in the same column having the same letter are not significantly different at 0.05 levels by Duncan's multiple rang test.

\section{Compactness}

Data in Table (3) showed that compactness (score) of artichoke heads was decreased with the prolongation of storage period. These results were in agreement with (Atala, 2006).

Concerning the effect of wrapping films, data revealed that there were significant differences between wrapping films and unwrapping (control). The highest score of head compactness were obtained by artichoke heads wrapped with polypropylene, polyethylene and polyvinyl films with no significant differences between them, while the lowest values of head compactness score were recorded from unwrapped (control).

As for the interaction between wrapping films and storage period, after 28 days of storage, heads wrapped in polypropylene film or polyethylene film had the highest compactness score with no significant differences between them, while unwrapped (control) recorded the lowest compactness score in the same period. These results were in agreement with (Gil-Izquierdo et al., 2002).

Table 3. Effect of different wrapping films on compactness (score) of artichoke heads during storage in 2017 and 2018 seasons.

\begin{tabular}{|c|c|c|c|c|c|c|}
\hline \multirow{2}{*}{ Treatments } & \multicolumn{5}{|c|}{ Storage period in days } & \multirow{2}{*}{ means } \\
\hline & Start & 7 & 14 & 21 & 28 & \\
\hline \multicolumn{7}{|c|}{ 2017season } \\
\hline Polypropylene film & $5.00 \mathrm{~A}$ & $5.00 \mathrm{~A}$ & $5.00 \mathrm{~A}$ & $5.00 \mathrm{~A}$ & $5.00 \mathrm{~A}$ & $5.00 \mathrm{~A}$ \\
\hline Polyethylene film & $5.00 \mathrm{~A}$ & $5.00 \mathrm{~A}$ & $5.00 \mathrm{~A}$ & $5.00 \mathrm{~A}$ & $4.67 \mathrm{AB}$ & $4.93 \mathrm{~A}$ \\
\hline Polyvinyl film & $5.00 \mathrm{~A}$ & $5.00 \mathrm{~A}$ & $5.00 \mathrm{~A}$ & $5.00 \mathrm{~A}$ & $4.33 \mathrm{BC}$ & $4.87 \mathrm{~A}$ \\
\hline Control (unwrapped) & $5.00 \mathrm{~A}$ & $5.00 \mathrm{~A}$ & $4.00 \mathrm{C}$ & $3.33 \mathrm{D}$ & $3.00 \mathrm{D}$ & 4.07 B \\
\hline Means & $5.00 \mathrm{~A}$ & $5.00 \mathrm{~A}$ & $4.75 \mathrm{~B}$ & $4.58 \mathrm{~B}$ & $4.25 \mathrm{C}$ & \\
\hline \multicolumn{7}{|c|}{2018 season } \\
\hline Polypropylene film & $5.00 \mathrm{~A}$ & $5.00 \mathrm{~A}$ & $5.00 \mathrm{~A}$ & $4.67 \mathrm{~A}$ & $4.67 \mathrm{~A}$ & $4.87 \mathrm{~A}$ \\
\hline Polyethylene film & $5.00 \mathrm{~A}$ & $5.00 \mathrm{~A}$ & $5.00 \mathrm{~A}$ & $4.67 \mathrm{~A}$ & $4.33 \mathrm{AB}$ & $4.80 \mathrm{~A}$ \\
\hline Polyvinyl film & $5.00 \mathrm{~A}$ & $5.00 \mathrm{~A}$ & $4.67 \mathrm{~A}$ & $4.67 \mathrm{~A}$ & $3.67 \mathrm{AC}$ & $4.60 \mathrm{~A}$ \\
\hline Control (unwrapped) & $5.00 \mathrm{~A}$ & $5.00 \mathrm{~A}$ & $3.67 \mathrm{~A}-\mathrm{C}$ & $3.00 \mathrm{BC}$ & $2.33 \mathrm{C}$ & $3.80 \mathrm{~B}$ \\
\hline Means & $5.00 \mathrm{~A}$ & $5.00 \mathrm{~A}$ & $4.58 \mathrm{AB}$ & $4.25 \mathrm{BC}$ & $3.75 \mathrm{C}$ & \\
\hline
\end{tabular}

Means in the same column having the same letter are not significantly different at 0.05 levels by Duncan's multiple rang test.

\section{Color}

Data in Table (4) showed that the color of the homogenized sample (L value and hue angle) was measured. The $\mathrm{L}$ value is measure of the highness of the artichoke heads while the hue angle represents a coordinate in a standardized color space. Lightness 
of artichoke heads was affected by storage time. A decrease in $\mathrm{L}$ value was detected by prolonging the storage period indicated darker color.

Regarding the effect of wrapping films, data revealed that artichoke heads wrapped with polypropylene or polyethylene film gave the highest value of $\mathrm{L}$ value, resulted in lighter color with no significant differences between them in the first season, while unwrapped heads gave the lowest value and resulted in darker color during storage. These results are in agreement with (Alexopoulos et al., 2003and Sergio et al., 2016).

In general, the interaction between wrapping films and storage periods were significant, after 28 days of storage, the highest value of $\mathrm{L}$ (score) was recorded from heads wrapped in polypropylene film, while the lowest ones were obtained from unwrapped film.

Table 4. Effect of different wrapping films on color ( $\mathrm{L}$ value) of artichoke heads during storage in 2017 and 2018 seasons.

\begin{tabular}{|c|c|c|c|c|c|c|}
\hline \multirow{2}{*}{ Treatments } & \multicolumn{5}{|c|}{ Storage period in days } & \multirow{2}{*}{ means } \\
\hline & Start & 7 & 14 & 21 & 28 & \\
\hline \multicolumn{7}{|c|}{ 2017season } \\
\hline Polypropylene film & $50.81 \mathrm{~A}$ & $40.33 \mathrm{CD}$ & $38.20 \mathrm{DE}$ & $45.03 \mathrm{~B}$ & $33.29 \mathrm{FH}$ & $41.53 \mathrm{~A}$ \\
\hline Polyethylene film & $50.81 \mathrm{~A}$ & $38.50 \mathrm{DE}$ & $35.40 \mathrm{EG}$ & $43.28 \mathrm{BC}$ & $30.10 \mathrm{HI}$ & $39.62 \mathrm{~A}$ \\
\hline Polyvinyl film & $50.81 \mathrm{~A}$ & $37.46 \mathrm{DF}$ & $31.20 \mathrm{GH}$ & $41.82 \mathrm{BD}$ & $26.20 \mathrm{IJ}$ & $37.50 \mathrm{~B}$ \\
\hline Control (unwrapped) & $50.81 \mathrm{~A}$ & $35.59 \mathrm{EG}$ & $29.40 \mathrm{HI}$ & $38.05 \mathrm{DE}$ & $23.20 \mathrm{~J}$ & $35.41 \mathrm{C}$ \\
\hline Means & 50.81 A & $37.97 \mathrm{C}$ & 33.55 D & 42.04 B & $28.20 \mathrm{E}$ & \\
\hline \multicolumn{7}{|c|}{2018 season } \\
\hline Polypropylene film & $48.60 \mathrm{~A}$ & $38.23 \mathrm{E}$ & $36.10 \mathrm{~F}$ & $42.93 \mathrm{~B}$ & $31.19 \mathrm{~K}$ & $39.41 \mathrm{~A}$ \\
\hline Polyethylene film & $48.60 \mathrm{~A}$ & $33.40 \mathrm{H}$ & $33.30 \mathrm{H}$ & $41.18 \mathrm{C}$ & $28.00 \mathrm{M}$ & $36.90 \mathrm{~B}$ \\
\hline Polyvinyl film & $48.60 \mathrm{~A}$ & $34.76 \mathrm{G}$ & $28.50 \mathrm{~L}$ & $39.12 \mathrm{D}$ & $23.50 \mathrm{O}$ & $34.90 \mathrm{C}$ \\
\hline Control (unwrapped) & $48.60 \mathrm{~A}$ & $32.89 \mathrm{I}$ & $26.70 \mathrm{~N}$ & $32.35 \mathrm{~J}$ & $20.50 \mathrm{P}$ & 32.21 D \\
\hline Means & $48.60 \mathrm{~A}$ & $34.82 \mathrm{C}$ & 31.15 D & $38.90 \mathrm{~B}$ & $25.80 \mathrm{E}$ & \\
\hline
\end{tabular}

Changes in hue angle values of artichoke heads are good indicator of senescence. As shown in Table (5) showed that the hue angle values of artichoke heads gradually decreased as the storage period extended indicating that artichoke heads turned to slight yellow as the storage period prolonged.

Concerning the effect of wrapping films on hue angle values, data revealed that artichoke heads wrapped with polypropylene film were more green color of heads (higher value of hue angle) as compared to those wrapped with polyethylene or polyvinyl film during storage. On the other hand, unwrapped heads gave the lower value of hue angle as an important degreening or intense yellowing. These results were true in the two seasons and were in agreement with those obtained by (Alexopoulos et al., 2003 and Sergio et al., 2016).

Table 5. Effect of different wrapping films on color (hue angle $h^{\circ}$ ) of artichoke heads during storage in 2017 and 2018 seasons.

\begin{tabular}{|c|c|c|c|c|c|c|}
\hline \multirow{2}{*}{ Treatments } & \multicolumn{5}{|c|}{ Storage period in days } & \multirow{2}{*}{ means } \\
\hline & Start & 7 & 14 & 21 & 28 & \\
\hline \multicolumn{7}{|c|}{ 2017season } \\
\hline Polypropylene film & $88.48 \mathrm{~A}$ & $86.21 \mathrm{~B}$ & $84.32 \mathrm{D}$ & $81.22 \mathrm{H}$ & $80.13 \mathrm{~J}$ & 84.07 A \\
\hline Polyethylene film & $88.48 \mathrm{~A}$ & $85.11 \mathrm{C}$ & $83.41 \mathrm{E}$ & $80.21 \mathrm{I}$ & $78.25 \mathrm{~K}$ & 83.09 B \\
\hline Polyvinyl film & $88.48 \mathrm{~A}$ & $83.21 \mathrm{~F}$ & $80.23 \mathrm{I}$ & $77.41 \mathrm{~L}$ & $75.25 \mathrm{~N}$ & $80.92 \mathrm{C}$ \\
\hline Control (unwrapped) & $88.48 \mathrm{~A}$ & $81.41 \mathrm{G}$ & $76.25 \mathrm{M}$ & $71.35 \mathrm{O}$ & $66.25 \mathrm{P}$ & $76.75 \mathrm{D}$ \\
\hline means & $88.48 \mathrm{~A}$ & 83.99 B & $81.05 \mathrm{C}$ & $77.55 \mathrm{D}$ & $74.97 \mathrm{E}$ & \\
\hline \multicolumn{7}{|c|}{2018 season } \\
\hline Polypropylene film & $91.26 \mathrm{~A}$ & $90.42 \mathrm{~B}$ & $88.23 \mathrm{C}$ & $86.24 \mathrm{E}$ & $84.25 \mathrm{~F}$ & 88.08 A \\
\hline Poly ethylene film & $91.26 \mathrm{~A}$ & $88.23 \mathrm{C}$ & $86.25 \mathrm{E}$ & $83.42 \mathrm{G}$ & $81.11 \mathrm{I}$ & 86.05 B \\
\hline Polyvinyl film & $91.26 \mathrm{~A}$ & 86.32 D & $84.21 \mathrm{~F}$ & $80.52 \mathrm{~J}$ & $78.24 \mathrm{~L}$ & 84.11 C \\
\hline Control (unwrapped) & $91.26 \mathrm{~A}$ & $83.25 \mathrm{H}$ & $80.11 \mathrm{~K}$ & $77.23 \mathrm{M}$ & $73.17 \mathrm{~N}$ & 81.00 D \\
\hline means & $91.26 \mathrm{~A}$ & 87.06 B & 84.70 C & 81.85 D & $79.19 \mathrm{E}$ & \\
\hline
\end{tabular}

Means in the same column having the same letter are not significantly different at 0.05 levels by Duncan's multiple rang test.

\section{Ascorbic acid content}

Data in Table (6) showed that ascorbic acid content of heads was significantly decreased with the prolongation of storage period. Similar results were obtained by (Atala, 2006). However, artichoke heads wrapped with different wrapping films hold more 
ascorbic acid content than unwrapped heads during storage. Whereas, the highest ascorbic acid content were obtained from wrapped heads in polypropylene followed by polyethylene film with significant differences between them in the two seasons. While the lowest one was recorded in unwrapped heads.
The aforementioned results were in accordance with those obtained by (Gil-Izquierdo et al., 2002) who reported that wrapping artichoke heads in polypropylene film kept comparatively the highest content of ascorbic acid than those stored in polyvinyl, polyethylene after 8 days of storage.

Table 6. Effect of different wrapping films on ascorbic acid content (mg/100gm f.w) of artichoke heads during storage in 2017 and 2018 seasons.

\begin{tabular}{|c|c|c|c|c|c|c|}
\hline \multirow{2}{*}{ Treatments } & \multicolumn{5}{|c|}{ Storage period in days } & \multirow{2}{*}{ means } \\
\hline & Start & 7 & 14 & 21 & 28 & \\
\hline & \multicolumn{5}{|c|}{ 2017season } & \\
\hline Polypropylene film & $72.00 \mathrm{~A}$ & $70.40 \mathrm{AB}$ & $65.00 \mathrm{AC}$ & $62.67 \mathrm{BD}$ & $54.67 \mathrm{DG}$ & $64.95 \mathrm{~A}$ \\
\hline Polyethylene film & $72.00 \mathrm{~A}$ & $66.00 \mathrm{AC}$ & $58.33 \mathrm{CF}$ & $52.00 \mathrm{FH}$ & 46.67 GI & 59.00 B \\
\hline Polyvinyl film & $72.00 \mathrm{~A}$ & $61.60 \mathrm{BE}$ & $53.33 \mathrm{EH}$ & $46.67 \mathrm{GI}$ & $40.00 \mathrm{IJ}$ & $54.72 \mathrm{C}$ \\
\hline Control (unwrapped) & $72.00 \mathrm{~A}$ & $55.00 \mathrm{DG}$ & $45.00 \mathrm{HI}$ & $38.67 \mathrm{IJ}$ & $32.00 \mathrm{~J}$ & 48.53 D \\
\hline \multirow[t]{2}{*}{ means } & $72.00 \mathrm{~A}$ & $63.25 \mathrm{~B}$ & $55.42 \mathrm{C}$ & $50.00 \mathrm{D}$ & $43.33 \mathrm{E}$ & \\
\hline & \multicolumn{5}{|c|}{2018 season } & \\
\hline Polypropylene film & $70.20 \mathrm{~A}$ & $68.20 \mathrm{~A}$ & $62.80 \mathrm{~B}$ & $57.14 \mathrm{CD}$ & $52.47 \mathrm{E}$ & $62.16 \mathrm{~A}$ \\
\hline Polyethylene film & $70.20 \mathrm{~A}$ & $63.40 \mathrm{~B}$ & $55.73 \mathrm{D}$ & $49.40 \mathrm{~F}$ & $44.07 \mathrm{G}$ & 56.56 B \\
\hline Polyvinyl film & $70.20 \mathrm{~A}$ & $59.40 \mathrm{C}$ & $51.13 \mathrm{EF}$ & $44.47 \mathrm{G}$ & $37.80 \mathrm{H}$ & $52.60 \mathrm{C}$ \\
\hline Control (unwrapped) & $70.20 \mathrm{~A}$ & $52.40 \mathrm{E}$ & $42.40 \mathrm{G}$ & $36.07 \mathrm{H}$ & $29.40 \mathrm{I}$ & 46.09 D \\
\hline means & $70.20 \mathrm{~A}$ & $60.85 \mathrm{~B}$ & 53.01 C & 46.77 D & $40.94 \mathrm{E}$ & \\
\hline
\end{tabular}

Means in the same column having the same letter are not significantly different at 0.05 levels by Duncan's multiple rang test.

From the previous results, it can be concluded that wrapping artichoke heads with polypropylene film produced an improvement in market quality; it would reduce weight loss percentage, color change and maintained ascorbic acid content and gave product with good appearance after 28 days of storage at $0{ }^{\circ} \mathrm{C}$ and $95 \%$ RH.

\section{References}

Alexopoulos, A.A.; K.A. Akoumianakis and H.C. Passam, 2003. The storage of globe artichokes under modified atmospheres. Food, Agric. Enviro., 1(2): 130-133.

Atala, S.A. 2006. Effect of some treatments for improving the quality and increasing storage ability of globe artichoke. M.Sc. Thesis, Fac. Agric. Cairo Univ., Egypt.

Azzini, E.; I. Pugianesi; F. Ronano; D. Venere; D. Miccadei and S. Durazzo, 2007. Absorption and metabolism of bioactive molecules after oral consumption of cooked edible heads of Cynarascolymus L. (Cultivar violettodiprovenza) in human subjects: a pilot study. British Journal of nutrition, 197(5): 963-969.

Gil-Izquierdo, A.; M.A. Conesa; F. Ferreres and M.I. Gil, 2002. Influence of modified atmosphere packaging on quality, vitamin Cand phenolic content of artichokes (CynarascolymusL.). Eur. Food Res. Technol., 215:21-27.

Helaly, A.A.; I.A.A. Haggag; S.A. Shanan; A.S.A. Abbo El-Hamd and R.E.I. El-Bassiouny, 2016. Effect of chemical treatments on the quality of fresh-cut globe artichoke (Cynarascolymus L.) during cold storage. Adv. Plants Agric. Res., 5(2):1-11.

Kader, A.A. 1992. Postharvest biology and technology: an overview. In A.A. Kader (ed.). Postharvest technology of horticultural crops. California: University of California Publications, P.15-20.

Lavermicocca, P.; M. Dekker; M. Russo; F. Valerio; F. Di Venere and D. Sisto, 2016. Lactobacillus paracasei-enriched vegetables containing health promoting molecules.In-R.R.Watson\& V.R. preedy (Eds.). Probiotics, prebiotics and synbiotics.Pioactive foods in health promotion (pp 361-370). San Diego, CA, USA: Elsevier Academic press.

Lucera, A.; A. Conte and M.A. Del Nobile, 2011. Shelf life of fresh-cut green beans as affected by packaging systems. Int. J. Food Sci. \& Technol., 46 (11): 2351-2357.

Mileo, A.M.; D. Di Venere; V. Linsalata; R. Fraioli and S. Miccadei, 2012. Artichoke polyphenols induce apoptosis and decrease the invasive potential the human breast cancer line MDAMB231. Journal of cellular physiology, 227: 3301-3309.

Nobile, M.A.; A. Conte; C. Scrocco; J. Laverse; I. Brescia; G. Conversa and A. Elia, 2009. New packaging strategies to preserve fresh-cut artichoke quality during refrigerated storage. Innovative Food Science and Emerging Technologies, 10: 128-133.

Ranganna, S. 1979. Manual of analysis of fruit and vegetable products. Central Food Techn. Rese. Institute .Oh.D. Published 12/4Asaf Ali ROAD, 
New Delhi 110002, and printed at raj Bandhu Industrial Company, C-16, May a puri, phase 11, New Delhi, 1100064.

Salazar, N.; A.M. Dewulf; A.M. Neyrinck; L.B. Bindels, P.D. Cani and L. Mahillon, 2015. Inulintype fructans modulate intestinal Bifidobacterium species populations and decrease fecal shortchain fatty acids in obese women. Clinical Nutrition, 34:501-507.

Sergio, L.; M.A. Gatto; L. Spremulli; M. Pieralice; V. Linsalata and D. Di Venere, 2016. Packaging and storage conditions to extend the shelf life of semi-dried artichoke hearts. LWT - Food Sci. and Techn. , 72: 277-284.

Snedecor, G.W. and W.G. Cochran, 1980. Statistical methods. $6^{\text {th }}$ Iowa State Univ. Press, USA.
Thompson, A.K. 1996. Post-harvest technology of fruits and vegetables, Cambridge, Mass: Blackwell Sci., No. 634.

Waller, R.A. and D.B. Duncan, 1969. A buyes rule for the symmetric multiple comparison problems. Amer. State. Assoc. J., 64:1484-1503.

Wang, C.Y. and L. Qi, 1997. Modified atmosphere package alleviates chilling injury in cucumbers. Postharvest Biol. and Technol., 10:195-200.

Wills, R.H.H.; T.H. Lee; D. Gerham; W.B. McGlasson and E.G. Hall, 1981. Postharvest and introduction to physiology and handling of fruits and vegetables. The AVF publishing Comp. Inc. estport. Conn., pp. 35.

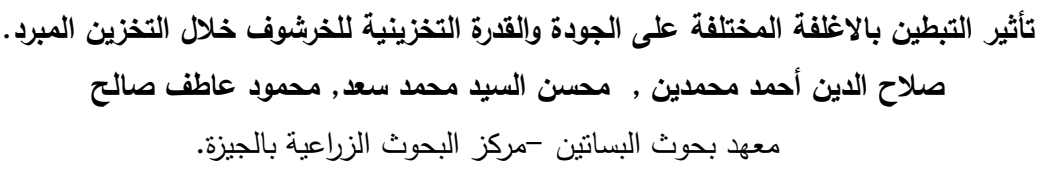

